\title{
Karyotypes of three species of toadfish (Batrachoididae: Teleostei) from Venezuela*
}

\author{
M. NIRCHIO ${ }^{1}$, B.J. TURNER ${ }^{2}$, J.E PÉREZ ${ }^{3}$, J.I. GAVIRIA ${ }^{1}$ and H. CEQUEA ${ }^{3}$ \\ ${ }^{1}$ Escuela de Ciencias Aplicadas del Mar. Universidad de Oriente, Isla de Margarita, Apartado Postal 630-Porlamar, \\ Venezuela. E-mail: nirchio@ci.udo.edu.ve \\ ${ }^{2}$ Department of Biology. Virginia Polytechnic Institute and State University, Blacksburg, VA 24061-0406. \\ ${ }^{3}$ Instituto Oceanográfico de Venezuela, Universidad de Oriente, Cumaná, Venezuela.
}

\begin{abstract}
SUMMARY: Karyotypes of three species of toadfish (Amphichthys cryptocentrus, Batrachoides manglae and Thalassophryne maculosa), reported here for the first time revealed diploid complements of 46 chromosomes. Karyo-evolutionary trend of these species is discussed. Based on differences in arm number, we suggest that $T$. maculosa possesses the most evolved karyotype among the three species, hence it would be the more recent one, followed by B. manglae and A. cryptocentrus.
\end{abstract}

Key words: karyotype, toadfish, Thalassophryne maculosa, Amphichthys cryptocentrus, Batrachoides manglae.

\section{INTRODUCTION}

The family Batrachoididae comprises three subfamilies and about 55 species (Nelson, 1984). Six species of batrachoid fishes in four different genera are known from Venezuelan waters: Amphychthys cryptocentrus, Batrachoides surinamensis, $B$. manglae, Porichthys plectrodon, P. pauciradiatus and Thalassophryne maculosa (Cervigón, 1993). Available information on the chromosomes of batrachoidid fishes is scanty. Chen (1967, cited by Sola $e t$ al., 1981) described a complement of 48 chromosomes in Porichthys notatus, but provided no details of configuration or arm number. Gutiérrez et al. (1984) reported on the effects of the inorganic mercury on the chromosomes of Halobatrachus didactylus but did not provide a description of chromosome morphology.

\footnotetext{
*Received May 25, 2000. Accepted April 2, 2001.
}

This paper reports the first description of the karyotype of A. cryptocentrus, B. manglae and $T$. maculosa, as a contribution to the cytogenetic documentation in Batrachoididae. These are the more common species in shallow waters from Margarita and Cubagua Islands, Venezuela. A. cryptocentrus is distributed from Panamá to Brazil; B. manglae is an endemic species from Venezuela while T. maculosa is distributed from Colombia to Trinidad and Tobago Islands.

\section{MATERIALS AND METHODS}

Ten specimens of each, Amphichthys cryptocentrus, Batrachoides manglae and Thalassophryne maculosa collected from shallow waters near Margarita Island, Venezuela, were used in the present study. Chromosome observations were made on preparations of cephalic portion of kidney, using the 
technique described in a previous paper (Nirchio and Cequea, 1998). A total of 100 mitotic spreads (10/individual) from each species were scanned to determine modal chromosome number. For analysis of chromosome morphology, high quality spreads with the modal number of chromosomes were photographed.

Chromosomes were arranged as described by Levan et al. (1964) and ordered according to decreasing size. Long arm (L), short arm (S) and length of whole chromosome were measured from each chromosome to the nearest $0.05-\mathrm{mm}$ using precision calipers. From these data, the L/S ratio was calculated. Chromosomes with arm ratios within the range 1.00-1.70 were considered to be metacentric (m); submetacentric (sm) if between 1.71-3.00; acrocentric (a) with ratios of 3.01 or greater. Number of arms (Fundamental Number: NF) was determined by considering $\mathrm{m}$ and sm chromosomes as biarmed. According to Elder et al. (1993) this classification scheme reduces subjective judgement in matters of resolution and results in a conservative estimate of chromosomal variation.

\section{RESULTS AND DISCUSSION}

All three species showed a modal diploid chromosome number of 46 . Counts of 46 chromosomes were obtained in $59-85 \%$ of all cells examined (Table 1). The hypomodal counts probably result from loss during preparation, chromosome overlap or miscounting. The few hypermodal counts probably represent additional chromosomes from another spread, a premature separation of chromatids, or additional chromosomes in atypical nuclei. Fig 1 shows the standard karyotype of the three species prepared by rearranging the chromosomes into groups based on $\mathrm{L} / \mathrm{S}$ ratio.

A. cryptocentrus presented a karyotype formula 4m:2sm:40a; T. maculosa karyotype formula was $8 \mathrm{~m}: 6 \mathrm{sm}: 32 \mathrm{a}$ and the formula for B. manglae was $6 \mathrm{~m}: 6 \mathrm{sm}: 34 \mathrm{a}$. No heteromorphic sex chromosomes were observed in the species for which sexually mature specimens were available ( $T$. maculosa). Arm number, obtained by assigning a value of 2 to biarmed chromosomes (metacentric and submetacentric) and a value of 1 to uniarmed chromosomes (acrocentric) was 52 for $A$. cryptocentrus, 58 for $B$. manglae, and 60 for T. maculosa. Biarmed chromosomes pairs were easily identified according to their morphology in each of the three species studied (Fig. 1). The rest of the chromosomes of these species could not be accurately classified as homologous pairs because differences in chromosome size and arm ratio were too slight between adjacent pairs within a size-graded series.

It has been suggested that the primitive karyotype of Teleosteans consisted of 48 acrocentric chromosomes (Gold, 1979; Ohno, 1974) and that deviations from the presumed ancestral karyotype were towards a reduction in the chromosome number by fusion of uniarmed elements to form large metacentric or submetacentric chromosomes (Doucette and Fitzsimons, 1988). This karyo-evolutionary trend seems to be supported by karyotype studies in twenty species of Elopiformes and Clupeiformes (Doucette and Fitzsimons, 1988) and by comparing chromosome complements of 24 species of North American Ictalurid catfishes, which resulted in a significant negative relationship $(\mathrm{P}<0.01$; $\left.r^{2}=0.745\right)$ between the number of large meta-submetacentric elements and diploid number (Le Grande, 1981).

Although the number of biarmed chromosomes is 6 for A. cryptocentrus, 12 for B. manglae, and 14 for T. maculosa, it should be noted that reduction in chromosome number in these species (with respect to the hypothetical ancestral karyotype) involves only a couple of chromosomes. Since arm number is rather variable (range from 52-60) in these three species, it appears likely that the group shares common chromosomal rearrangements involving centric fusion of two pairs of uniarmed chromosomes, resulting in the decrease in diploid number from the hypothetical complement (48 acrocentric elements)

TABle 1. - Distribution of diploid chromosome counts in the three species of Batrachoididae from Margarita Island, Venezuela.

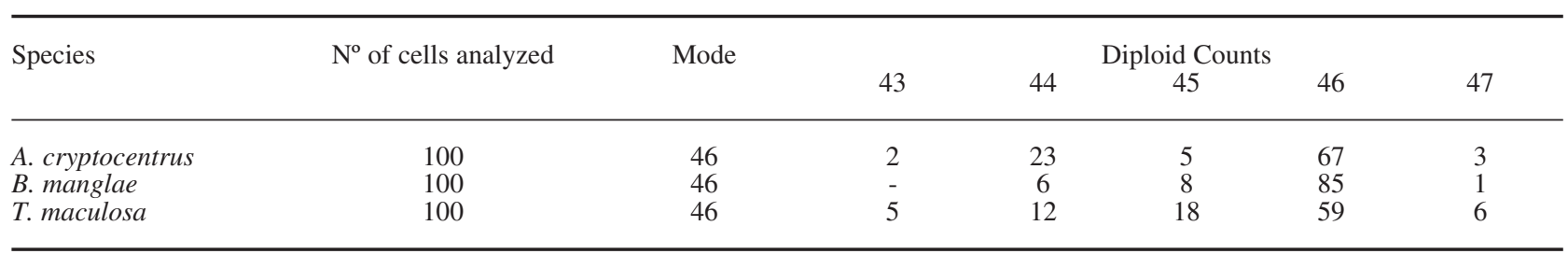


Fig. 1. - Standard karyotypes of Amphichthys cryptocentrus (A), Batrachoides manglae (B) and Thalassophryne maculosa (C). Abbreviations: m, metacentric; sm, submetacentric, and a, acrocentric.

to the current karyotype of 46 . The rest of biarmed chromosomes in each species could be derived from a variable number of pericentric inversions or unequal reciprocal translocations between acrocentric chromosomes.

If the trend towards the reduction of chromosomes as a consequence of centric fusions (Robertsonian rearrangements) of uniarmed chromosomes holds true, and keeping in mind that pericentric inversions and reciprocal translocations are all rare events that are plausibly maintained in the population only if they represent an adaptive advantage, then the accumulation of these chromosomal rearrangements could be correlated with the phylogeny of the species. That is to say: species with high arm number would be species of more recent appearance in the evolutionary history of the lineage. In other words, low NF should be a plesiomorphy and high NF an apomorphy.

Since T. maculosa possesses the most derived karyotype among the three studied, it is proposed that it would posses the more evolved karyotype, followed by B. manglae and A. cryptocentrus. In fact, this point of view is supported by the more specialized condition of the genus Thalassophryne within the Batrachoididae, taking into account meristic features and the presence of the most high- ly developed venom apparatus of any fish species, as described by Collette (1966).

An inherent problem of cytogenetic studies without applying banding techniques is that we can not know the amount of homoplasy of chromosomal characters, i.e., karyotype rearrangements present on a certain species may be present (or not) in other species, closely related or not. This problem tends to limit the extent to which phylogenetic methods of analysis can be applied to the data, and presents an important caveat to the accuracy of our interpretation of phyletic trends in this group.

\section{REFERENCES}

Cervigón, F. - 1993. Los peces marinos de Venezuela. $2^{\text {a }}$ Edición. Volumen II. Fundación Científica Los Roques, Caracas, Venezuela.

Chen, T.R. - 1967. Comparative karyology of selected deep-sea and shalow water Teleost fishes. Ph. D. Thesis. Yale University, New Haven, Conn.

Collette, B.B. - 1966. A review of the venomous toadfishes, subfamily Thalassophryninae. Copeia, 4: 846-864.

Doucette Jr., A.J. and J.M. Fitzsimons. - 1988. Karyology of Elopiform and Clupeiform fishes. Copeia, 1: 124-130.

Elder, J.F, B.J Turner, J.E Thomerson and D.C. Taphorn. - 1993. Karyotypes of nine Venezuelan annual killifishes (Cyprinodontidae), with comments on karyotype differentiation in annual killifishes. Ichthyol. Explor. Freshwater, 4(3): 261-268.

Gold, J. - 1979. Cytogenetics. In: W.S. Hoar, and D.J. Randall (eds.), Fish Physiology, Volume 8, pp, 353-405. Academic Press, New York. 
Gutiérrez, M, C. Sarasquete and R. Establier. - 1984. Nota sobre los efectos del mercurio inorgánico $\left(\mathrm{HgCl}_{2}\right)$ en los cromosomas del pez sapo marino, Halobatrachus didactylus S. Inv. Pesq. 48(2): 181-185.

Legrande, W.H. - 1981. Chromosomal Evolution in North American Catfishes (Siluriformes: Ictaluridae) with Particular Emphasis on the Madtoms, Noturus. Copeia, 1: 33-52.

Levan, A., D. Fredga and A. Sandberg. - 1964. Nomenclature for centromeric position on chromosomes. Hereditas, 52: 201-220.

Nelson, J.S. - 1984. Fishes of the world. A Wiley-Interscience publication.
Nirchio, M. and H. Cequea. - 1998. Karyology of Mugil liza and M. curema from Venezuela. Bol. Invest. Mar. Cost. 27: 45-50.

Ohno, S. - 1974. Protochordata, Cyclostomata and Pisces. In: John, B. (ed.), Animal Cytogenetics, vol. 4. Getrüder Borntaerger, Berlin.

Sola, L., S. Cataudella and E. Capanna. - 1981. New developments in vertebrate cytotaxonomy. III. Karyology of Bony Fishes: a review. Genetica, 54: 285-328.

Scient. ed.: F. Piferrer 